Portland State University

PDXScholar

Economics Faculty Publications and

Presentations

Economics

6-1-2010

\title{
Are Biotechnology and Sustainable Agriculture Compatible?
}

\author{
David E. Ervin \\ Portland State University \\ Leland L. Glenna \\ The Pennsylvania State University \\ Raymond Adelard Jussaume \\ Washington State University
}

Follow this and additional works at: https://pdxscholar.library.pdx.edu/econ_fac

Part of the Agricultural Economics Commons, and the Sustainability Commons

Let us know how access to this document benefits you.

\section{Citation Details}

Ervin, D. E., Glenna, L. L., and Jussaume Jr., R. A. (2010). Are biotechnology and sustainable agriculture compatible? Renewable Agriculture \& Food Systems, 25(2), 143-157.

This Article is brought to you for free and open access. It has been accepted for inclusion in Economics Faculty Publications and Presentations by an authorized administrator of PDXScholar. Please contact us if we can make this document more accessible: pdxscholar@pdx.edu. 


\title{
Are biotechnology and sustainable agriculture compatible?
}

\author{
David E. Ervin ${ }^{1 *}$, Leland L. Glenna ${ }^{2}$ and Raymond A. Jussaume $\mathrm{Jr}^{3}$ \\ ${ }^{1}$ Center for Sustainable Processes and Practices, Portland State University, Portland, Oregon 97201, USA. \\ ${ }^{2}$ Department of Agricultural Economics and Rural Sociology, The Pennsylvania State University, University Park \\ PA 16802, USA. \\ ${ }^{3}$ Department of Community and Rural Sociology, Washington State University, Pullman, WA 99163, USA. \\ ${ }^{*}$ Corresponding author: dervin@pdx.edu
}

\begin{abstract}
Agricultural biotechnology has been largely opposed by advocates in the sustainable agriculture movement, despite claims by the technology's proponents that it holds the promise to deliver both production (economic) and environmental benefits, two legs of the sustainability stool. We argue in this paper that participants in this polarized debate are talking past each other because assumptions about biotechnology and sustainability remain simplistic and poorly defined. Genetically engineered (GE) herbicide-resistant and insect-resistant crop varieties are the most visible current forms of agricultural biotechnology, and thus the form of biotechnology that many in the sustainability movement react to. However, these crops represent a biotechnology option that has paid insufficient attention to the integrated and systemic requirements of sustainable agriculture. In particular, common definitions of sustainable agriculture reinforce the need to include consideration of socio-economic distributive or equity effects into any assessment of sustainability. However, the frameworks that have been proposed to assess the potential for GE crops to enhance sustainable agriculture generally neglect this essential socio-economic dimension. We present an analysis that augments the sustainability frameworks to include the full suite of environmental, economic and social impacts. A review of the latest science on each impact category reveals that crop biotechnology cannot be fully assessed with respect to fostering a more sustainable agriculture due to key gaps in evidence, especially for socio-economic distributive effects. While the first generation of GE crops generally has made progress in reducing agriculture's environmental footprint and improving adopting farmers' economic well-being, we conclude that these early products fall short of the technology's capacity to promote a more sustainable agriculture because of the failure of those developing and promoting the technology to fully engage all stakeholders and address salient equity issues. To realize the sustainability potential of biotechnology will require fundamental changes in the way public and private research and technology development and commercialization are structured and operated. We identify new approaches in these areas that could make this powerful biological science more compatible with sustainable agriculture.
\end{abstract}

Key words: biotechnology, sustainable agriculture, environmental, economic, social, socio-economic, equity

\section{Introduction}

The debate over whether biotechnology is not only compatible with, but can actually be used to promote, sustainable agriculture has gone on for at least three decades. Proponents of using crop biotechnology as part of a strategy to achieve a more sustainable agriculture emphasize how this technology has helped increase production while reducing some of the environmental impacts associated with cropping practices ${ }^{1}$. Officials of Monsanto, Dow Agrosciences, Dupont and Syngenta, firms that produce the vast majority of genetically engineered (GE) seeds, echo that theme and contend that biotechnology promotes sustainability because it increases production and farmer profits while reducing pesticide usage. They also emphasize that biotechnology holds the promise to develop new crop varieties that could thrive under adverse environmental conditions such as drought ${ }^{2}$. Some university scientists and government officials support claims that using GE techniques can be compatible with sustainable agriculture $^{3}$ (for a critique see Lyson ${ }^{4}$ ). This parallels the claims made by some academic researchers that the use of GE crop technology, under appropriate conditions, could be compatible with organic farming ${ }^{5,6}$.

Despite these claims, crop biotechnology has largely been opposed by sustainable and organic agriculture 
advocates. For example, the use of GE crops was not prohibited under draft guidelines for organic agricultural production that were proposed by the United States Department of Agriculture (USDA). However, after receiving over 275,000 letters, most of which were opposed to allowing GE crops in organic production systems, the USDA changed its position and prohibited the use of GE crops within its final national organic standards ${ }^{7-10}$. This case symbolizes the substantial resistance to the use of biotechnology, including by those who are not directly involved in organic agricultural production. If this opposition continues, the sustainable agriculture movement may not take full advantage of transgenic technologies, tissue culture, advanced genetics and other manifestations of the latest advances in molecular and cellular biology available to crop scientists ${ }^{11}$.

The basic contours of the debate follow in the footsteps of more longstanding arguments between proponents of modern 'high-yield' farming and critics of industrialization $^{12}$. Those critics often contend that biotechnology is treated as a magic bullet ${ }^{13}$ that can 'make deserts bloom, clean our soils, our oceans and our air, feed the world, end disease, make all our children tall and strong and perfect...' (p. 397) ${ }^{14}$, while ignoring the social, economic and political contexts surrounding modern agricultural production systems. Other critics argue that biotechnology is a high-risk technology that, at best, represents a minor progression in the ongoing industrialization of agricultural production systems, and that any resultant productivity improvements will have a nominal impact on addressing ongoing environmental and socio-economical issues, such as hunger and food insecurity, that are associated with industrialized agri-food systems ${ }^{15}$. Longstanding debates about industrialized farming have shifted to questions about addressing environmental problems and ramping up crop production for biofuels. Proponents of agricultural biotechnologies argue that GE crop technologies are the best hope for agriculture to contribute to the sustainable development of the planet ${ }^{2}$. Critics counter that the technologies not only fail to advance society toward more sustainable agricultural systems, but in some cases lead to greater long-term ecological risks, net energy deficits, economic losses and social harms ${ }^{16,17}$.

To understand the nature of the conflict, it is helpful to distinguish between the scientific techniques and applications and the philosophical perspectives that shape opposing positions ${ }^{18}$. Much of the debate about the potential for agricultural biotechnology to contribute to agricultural sustainability has focused on three issues: technical efficacy and economic efficiency of the technology (mainly in pest control), human health impacts and effects on animal and environmental well-being. What tends to receive less attention is the socio-economic distributive, or social equity, effects of a new product or technology ${ }^{19}$. Given that the social justice aspect of sustainable agriculture often directly addresses some of the most problematic aspects of an industrialized agri-food system, such as maintaining small and mid-sized farms and providing living wages for farm workers, it is not surprising that there is a call to more directly address issues of equity in the agri-food system, as well as to distinguish between environmental and social justice issues $^{20}$.

As one of the principal legs of most definitions of sustainability, we argue that concerns about socio-economic equity must be an essential component of any assessment about whether a technology will foster more sustainable agricultural development. Interestingly, this socio-economic equity criterion is comparatively more prominent in European discussions than in the USA ${ }^{19,21}$. Commenting on the rejection of agricultural biotechnology by the organic agriculture community in the UK, Reed ${ }^{22}$ contends that the rationale was not based on a categorical rejection of biotechnology. Rather, the decision was based on a critique of the political-economic structures behind biotechnology research and development. UK organic farmers were skeptical that the technology would truly be applied to solve the most pressing economic, ecological and social equity problems, rather than be a tool that primarily serves capital accumulation for the firms who have legal ownership of the technology. Further, UK organic farmers had serious questions about whether the stream of crop biotechnologies that had been produced until that time satisfied other basic tenets of sustainable agriculture, such as fostering cropping systems resilient to uncertain future stresses $^{21}$.

In contrast, when considering regulatory approval of recombinant bovine somatotropin (rBST), the US government agency in charge of regulating the technology noted that 'At no time in the past has the U.S. Federal Government prevented a technology from being adopted on the basis of socioeconomic consequences ${ }^{19}$. The Federal Government's position does not mean that the socio-economic criterion is not important to US farmers, consumers and observers. Pfeffer has described how the sustainable agriculture movement emerged in the USA to challenge the trend of farmers becoming more dependent on purchasing agribusiness inputs from off-farm sources ${ }^{23}$. Furthermore, a US National Research Council report argued that it was important to address social, behavioral, economic and ethical aspects of new technologies ${ }^{24}$. However, the use of this socio-economic criterion has not been fully embraced in policy and business circles.

The consideration of socio-economic distributive impacts of a technology enlarges the lens through which we view sustainable agriculture, as well as providing an important vehicle for maintaining the systemic perspective that is so essential to any conceptualization of development, including sustainable development ${ }^{25}$. In other words, one cannot judge the potential impact of GE crops on improving agricultural sustainability solely by assessing the impacts on environmental health and/or profitability. Agricultural biotechnology cannot be declared to be conducive to a more sustainable agriculture if it reduces environmental impacts and improves economic conditions for adopting 
farmers, but also fails to address salient social equity issues with respect to farmers, farm and food industry workers, consumers and human communities. For example, a full sustainability assessment requires information on the impacts of biotechnology on the structural shift toward fewer and larger farms, vertical and horizontal consolidation of agribusiness that diminishes input and marketing options, farmers' dependence on off-farm suppliers with market power, the creation of a sustainable standard of living for all those who work in the agri-food industry, and food access and nutrition issues for vulnerable populations $^{4,19}$.

Of course, no technology can be expected to resolve all these problems. Indeed, the point we hope to make is that technologies alone do not solve socio-economic problems. Biotechnology proponents tend to make sweeping claims about how new breakthroughs will bring sustainability. However, those technologies are developed and applied within specific socio-economic contexts. Developing and implementing a new technology into a socio-economic context that is not structured to promote sustainability, e.g., lacking access for key stakeholders, will fail to achieve sustainability.

As we explain below, information about how agricultural biotechnology may or may not be contributing to the improvement of the socio-economic conditions of all those who have a stake in the agri-food system is much sparser than for its environmental and economic dimensions. This paper highlights the need for a careful and integrated consideration of what sustainable agriculture is in terms of the full suite of ecological, economic and social considerations. After defining the premises and principles of sustainability, we examine the compatibility of agricultural biotechnology, focusing on GE crops, with those premises and principles.

\section{Sustainable Agriculture}

As is generally the case with contested and widely used academic concepts, it is difficult to pin down a single definition of sustainable agriculture because there are hundreds of definitions of sustainability, sustainable development and sustainable agriculture. Indeed, the existence of multiple definitions contributes to the 'joy', and perhaps the power, of the concept of sustainability ${ }^{26}$. Perhaps the most cited definition of sustainability with respect to agriculture is the one adopted by the USDA, which was codified into law in the 1990 Food, Agriculture, Conservation and Trade Act and reaffirmed in subsequent farm bills. Under that law, the term 'sustainable agriculture' means an integrated system of plant and animal production practices having a site-specific application that will, over the long term:

- 'satisfy human food and fiber needs;

- enhance environmental quality and the natural resource base upon which the agricultural economy depends;
- make the most efficient use of non-renewable resources and on-farm resources and integrate, where appropriate, natural biological cycles and controls;

- sustain the economic viability of farm operations and

- enhance the quality of life for farmers and society as a whole. $^{27}$

Lyson $^{4}$ has noted that this definition is important for emphasizing economic, ecological, social and community dimensions of agriculture. Salient aspects include the emphasis on an integrated system and the inclusion of elements addressing environmental, natural resource, economic and social quality of life dimensions.

To more fully appreciate the complexity, and more significantly the holistic, integrated nature, of definitions of sustainable agriculture, it is informative to recognize how the concept of sustainable agriculture developed historically in contradistinction to conventional industrial agriculture. Similar to Pfeffer ${ }^{23}$, Harwood ${ }^{28}$ has argued that the sustainability movement in agriculture emerged and grew throughout the 1900s alongside continuing agricultural industrialization. He locates a divide between the 'systematic agriculturalists', who supported the industrialization model, and the 'scientific agriculturalists', who sought to work with nature as natural historians. For Harwood, the key difference in these two approaches to agriculture lies in reductionism versus holism. The biodynamic principles that emerged from the scientific agriculturalist movement included 'diversification, recycling, avoiding chemicals, decentralized production and distribution ...' (p. 7) $)^{28}$. The organic farming and agroecological movements both emerged from this broader scientific agriculturalist movement, sharing similar themes of wholeness, ecology and an appreciation for traditional farming practices, even if the applications may vary. After surveying these various strands of the sustainable agriculture movement, Harwood highlights three basic principles of sustainable agriculture:

- 'The interrelatedness of all parts of a farming system, including the farmer and his (sic) family.

- The importance of the many biological balances in the system.

- The need to maximize desired biological relationships in the system and to minimize use of material and practices that disrupt those relationships' (p. 12) ${ }^{28}$.

Harwood explains how these principles have been converted into a plan for action:

- 'Agriculture must be increasingly productive and efficient in resource use.

- Biological processes within agricultural systems must be much more controlled from within (rather than by external inputs of pesticides).

- Nutrient cycles within the farm must be much more closed' (p. 15) ${ }^{28}$.

Following a similar approach in distinguishing between conventional industrial agriculture and sustainable agriculture, Lyson ${ }^{4}$ argues that agricultural biotechnology 
highlights the divide between two radically opposed socioeconomic and biological paradigms. He contends that the conventional agricultural paradigm combines the reductionist approaches of experimental biology and neoclassical economics as it strives to maximize productivity and efficiency. In such a paradigm, he argues, the role of those who work the land and handle the food is reduced for the most part to the role of 'inputs'. In the contrasting paradigm, 'sustainable agriculture denotes a holistic, systems-oriented approach to farming that focuses on the interrelationships of social, economic, and environmental processes' (p. 195) ${ }^{4}$. In this paradigm, interrelationships between people, and between people and nature, are all emphasized. Lyson further argues that biotechnology fits squarely within the reductionist paradigm and is, therefore, incompatible with sustainability.

This notion of two opposing approaches to understanding agricultural development to a certain extent parallels the theories of weak and strong sustainability that have been developed by neoclassical and ecological economists, respectively ${ }^{29,30}$. The weak sustainability model treats all forms of capital-natural, manmade, human and social/ institutional-as substitutes without constraints on their substitution in furthering sustainable development. In this basically reductionist formulation, if a natural resource, such as pest susceptibility, is depleted, manmade capital, such as GE seed, or human or social capital can replace its function without loss of welfare for future generations. Conversely, the strong sustainability model posits that certain natural resources serve as complements, not substitutes, to using other forms of capital in holistic systems ${ }^{31}$. An example might be the perceived need for minimum levels of biological diversity in plants and insects to ensure that adequate pools of resistance and susceptibility exist to assure effective pest control strategies in growing crops. Ironically, the refuge strategy now employed for transgenic insect-resistant (IR) crops using the soildwelling bacterium Bacillus thuringiensis (Bt) recognizes this complementary relationship ${ }^{32}$. Nonetheless, the current generation of GE crops for the most part perpetuates the reductionist management tactic of relying on pesticides to control weeds and insects, an approach that generally leads to resistance development ${ }^{33}$. The use of such pesticides generally violates the principle of relying primarily on natural biological processes and balances as articulated by Harwood.

Using Lyson's approach, it could be argued that the vast majority of agricultural biotechnological applications have not been advanced as parts of holistic management systems, but rather have been reductionistic approaches to individual problems, e.g., weed or insect control. However, Lyson fails to address the question in his work of whether biotechnology could be part of a research program that fits within the sustainability paradigm. Is biotechnology inherently reductionist, or could biotechnological tools be used by 'scientific agriculturalists' to develop a greater amount of agricultural diversity, including varieties of agricultural crops that are targeted to thrive in specific ecological niches with minimal use of external inputs, such as host plant resistance to viruses developed with intragenic techniques ${ }^{3}$, and that specifically address the needs and challenges facing at-risk farmer populations?

Hubbell and Welsh ${ }^{34}$ provide a nuanced approach to understanding the existing and potential role of technology in sustainable and conventional agricultural systems when they portray these as opposing systems on a continuum rather than as part of a discrete dichotomy. On the conventional end of the continuum is a system based upon heavy chemical usage in the production of extensive acreage of a few, genetically similar crops. On the other end is low-input (and organic), multi-crop and integrated livestock production systems. Farmers who seek to reduce chemical usage and adopt other ecologically friendly practices may not be following fully sustainable practices, but they may be moving along the continuum from less to more sustainable.

Using this continuum, Hubbell and Welsh ${ }^{34}$ offer three scenarios in which GE crops that enhance the transition of agriculture from less to more sustainable could be developed. The first is transgenic crops that could reduce the use of the most harmful agricultural chemicals within an agricultural system characterized by monocropping and socio-economic concentration. An example would be herbicide-resistant (HR) crops. These crops enable the use of a more environmentally benign chemical to control weeds, such as glyphosate, although it remains a chemicalintensive form of production that is based upon extensive socio-economic hierarchies.

In the second scenario, transgenic crops could be useful in helping farmers transition out of a chemical-intensive agriculture. In this case, crops designed to produce their own pesticides can serve to replace the application of harmful chemicals. The application of the current portfolio of Bt crops exemplifies this scenario. However, these crops are not fully sustainable because gene flow and pest resistance build-up remain persistent challenges. Also, as is the case with the first scenario, various social issues, such as farm structural conditions, seed access and food distribution issues, are not addressed. However, this second scenario may be considered to be promoting a stronger movement toward sustainable practices than scenario one.

The third scenario lays out the possibility that transgenic crops could be instrumental in helping promote an integrated pattern of sustainable agricultural development. 'Potential benefits of these types of transgenic crops include reduced toxic chemical use, higher yields or improved output quality, reduced costs of production, reduced soil erosion, and increased farmer control and autonomy over the production process' (p. 48) ${ }^{34}$. Currently, to our knowledge, there are very few transgenic crop developments fitting this description. In a rare example, Baum et al. ${ }^{35}$ report positive laboratory findings that ribonucleic-acid (RNA) interference technology, a plant-based method for pest management, causes larval stunting and mortality in 
several coleopteran species controlled by Bt crops. However, for this crop to fit into the third scenario, it would be necessary to address the socio-economic equity criteria. The authors recognize this by noting that 'long-term sustainability in conjunction with the use and development of transgenic crop varieties will require reforms in both industry structural arrangements and the research agendas of public institutions and private sector firms' (p. 54) ${ }^{34}$.

This tripartite framework laid out by Hubbell and Welsh is a useful one ${ }^{34}$. We use it to analyze whether developments in transgenic crops could enhance the development of sustainable agricultural systems, which includes recognition of the need to directly address socio-economic dimensions in advancing agricultural sustainability. Indeed, one limitation of the Hubbell and Welsh framework is the lack of emphasis on socio-economic factors in their scenarios, even though they do mention the importance of such factors ${ }^{34}$. We thus expand on Hubbell and Welsh by elevating the consideration of socio-economic factors into a full sustainability assessment of GE crops.

We emphasize that the quest for a more sustainable agriculture will be an ongoing process of learning and adaptation to a multitude of uncertain developments. In other words, sustainability is a perpetually evolving, dynamic process. The Hubbell and Welsh analysis and the USDA and Harwood definitions imply this process of experimentation and adaptation to achieve balance and integration of environmental, economic and social elements within a system. Therefore, as the conditions surrounding climate change, water shortages and energy insecurity unfold, national and global social, economic and political institutions change, and the public and private science of molecular and cellular biology evolve, the potential opportunities and challenges for agricultural biotechnology in contributing to sustainable agriculture will also change.

\section{Current GE Crop Status}

The Flavr Savr tomato was the first commercially available transgenic crop, approved in 1994 but subsequently withdrawn $^{35}$. Since then, a small number of crops have been engineered to provide herbicide resistance and insect resistance. These crops have become widespread and commercially successful. In the USA, HR, IR and combinations (stacks) of the two GE traits were used on 80-92\% of acres planted to soybean, cotton and corn in $2008^{36}$. These acreages account for approximately half of all cropland planted in the USA, although these crops account for a minority of the commercial agricultural commodities grown in the nation.

Adoption rates for these crops in the rest of the world are generally lower, but substantial and growing. Since 1996, an additional 29 countries have granted regulatory approval for GE crops for imports for food and feed use and for release into the environment. Twenty-five countries (including 15 developing countries) had farmers plant some GE crops in 2008. During 2008, GE soybeans accounted for
$53 \%$ of the global biotech crop area, followed by corn at $30 \%$, cotton at $12 \%$ and canola at $5 \%$. By 2008, 309 million acres of land were grown with GE cultivars worldwide, about $94 \%$ of which were in six countries: USA, Brazil, Argentina, Canada, China and India. Over $90 \%$ of the 13.3 million farmers growing GE crops in 2008 were small and resource-poor farmers in developing countries. The remaining approximately 1 million were large farmers, primarily from developed countries. Of the $\$ 7.5$ billion global biotech crop market, less than one-quarter was in the developing countries ${ }^{37}$.

\section{GE Crops and Sustainable Agriculture Principles}

We continue our analysis by summarizing the performance of GE crops with respect to the three pillars of sustainability science-environmental, economic and social-as well as judging their fit within the Hubbell and Welsh scenarios. Not surprisingly for a technology in its initial phases of commercialization, the bodies of knowledge on each dimension are variable and incomplete.

\section{Environmental Impacts}

The enhancement of environmental quality and the natural resource base, on and off the farm, constitutes a central principle of the Farm Bill's and Harwood's sustainable agriculture definitions. Early assessments of the environmental impacts of transgenic crops found a lack of comprehensive scientific evidence with which to draw definitive conclusions about many of the impacts ${ }^{38,39}$. However, much research has been conducted on these issues during the past decade that helps to explain both the potential and limitations of GE crops with respect to environmental management.

The general contention of analyses supported by industry $^{1}$ is that GE crops have been an environmental winner, reducing pesticide use and toxicity levels, fostering wider use of no-till and conservation tillage methods that reduce erosion, polluted runoff and carbon emissions, and all while not incurring significant environmental risks from effects on soil biota, gene flow and pesticide resistance. Studies sponsored by groups who generally oppose the current generation of GE crops challenge those assertions and conclude that any environmental benefits will be partial and short-lived due primarily to resistance build-up ${ }^{16,17}$.

The latest evidence does not support either polar position on environmental impacts, instead painting a more nuanced picture of early, but tenuous, benefits on some fronts because of increasing resistance problems especially for HR crops, and incomplete evidence on many salient questions because of inadequate research. For example, there is robust evidence that the use of $\mathrm{Bt}$ cotton and corn has decreased the level and toxicity of insecticide use on those crops ${ }^{40,41}$. The pesticide reduction effect can extend beyond the adopting farm boundaries as some evidence 
shows that $\mathrm{Bt}$ crops influence regional pest population dynamics $^{42}$. Furthermore, the EPA-mandated refuges that must accompany the planting of Bt crops appear to have stemmed insect resistance development to this date $e^{43,44}$.

The use of IR crops with the soil-dwelling Bt bacterium, a material that is acceptable for pest control in organic agriculture, is a good case for analyzing potential compatibility with sustainable agriculture principles. By substituting a biological pesticide control for synthetic chemical pesticides, this particular use of GE technology fits within Hubbell and Welsh's second scenario of moving toward more sustainable agriculture methods. However, if not managed responsibly, it is subject to risks, in particular an increase in pest resistance to the Bt agent, and the possibility that farmers will return to more toxic pesticides. The strategy of maintaining minimum refuge sizes, e.g., field border zones, in non-GE crops has effectively deterred resistance, as noted above. While these IR crops have lessened the load and toxicity of alternative pesticides and have not caused deleterious effects on other biological species to date, they often are not part of cropping systems that maximize desired biological relationships that help close nutrient cycles, or that improve natural water cycles. There is evidence that $\mathrm{Bt}$ crops can promote integrated pest management, which could be seen as a step in that direction $^{32}$. In general, Bt crops cannot be judged a technology that fully supports the holistic environmental orientation embedded in the sustainable agriculture approach at this point in time. Such advances may come in future generations of the technology.

HR crops have had uneven effects on pesticide use, altering the mix of compounds employed, in particular substituting glyphosate for other herbicides ${ }^{40}$. Data are inconclusive about whether the total amounts of herbicide active ingredients have declined with HR crops or increased $^{17}$. However, it is generally believed that the overall toxicity of herbicides has declined because glyphosate is more environmentally benign than the chemicals it replaces ${ }^{45,46}$. Also, several studies have found that the adoption of HR crops fosters increased use of no-till and other conservation tillage methods that, in turn, reduce soil erosion and polluted runoff, although the causative effects run in both directions and the relative importance of each driver has not been determined ${ }^{47-49}$.

The prominent use of HR technology within GE crop development suggests that the current applications of transgenic crops are not addressing the full set of ecological sustainability issues related to agriculture. One can argue, as Hubbell and Welsh ${ }^{34}$ suggest, that HR crops may be characterized as a small shift from conventional to sustainable agriculture. As noted, HR crops enable adopting farmers to utilize a comparatively more environmentally benign chemical (glyphosate) than those used in conventional, non-organic cropping. However, Hubbell and $\mathrm{Welsh}^{34}$ also point out that engineering a plant to replace one agricultural chemical with a comparatively more benign one does not change the ongoing reliance on external chemical inputs. Furthermore, the continued reliance of GE crops on off-farm nutrients violates the sustainable agriculture principle of making nutrient cycles more closed ${ }^{28}$.

Perhaps the two most pressing environmental issues associated with HR crops are the growing threat of weed resistance to glyphosate, which could cause a return to the use of more toxic herbicides, and potential gene flow problems ${ }^{50-53}$. The risk of growing resistance to GE crops is inherent in the modern pesticide paradigm ${ }^{33}$. When glyphosate-resistant crops are planted and glyphosate becomes the predominant means of weed control, the weeds that survive can more rapidly evolve resistance to glyphosate. As a result, 'large-scale reliance on glyphosate for weed management has increased high-fitness habitat and will result in rapid spread of glyphosate-resistant weeds' (p. 1) ${ }^{54}$. Scientists have discovered resistance in at least 12 agronomically important weeds. Industry has responded by seeking to genetically engineer crops to be resistant to dicamba. Dicamba is considered to be less environmentally benign than glyphosate ${ }^{55}$. Hubbell and Welsh ${ }^{34}$ suggest that transgenic crops developed for pest and virus resistance, and other traits, may move crops in a more sustainable direction than those designed to be tolerant to herbicides.

Gene flow was considered a serious threat by scientists who recognized as early as the mid-1980s that transgenes could spread from GE crops to non-GE crops and to wild relatives. However, scientists largely assumed at the time that the gene flow and subsequent impacts would be limited. Subsequent research on GE crops suggested that potential gene flow was far more extensive than originally assumed $^{56,57}$. The presumed consequences are two-fold. First, gene transfer from crops to their wild relatives could limit the future effectiveness of herbicides now in use. Second, gene flow from one crop to another could create additional problems, such as the example of transgene flow to volunteer canola plants that can develop resistance to multiple herbicides ${ }^{56}$.

Research on gene flow highlights the complexity of understanding the ecological consequences. For example, gene flow from transgenic squash to wild relatives may have an indirect consequence of enhancing the feeding preference of a non-target pest: the cucumber beetle. Furthermore, the squash's wild relatives are common weeds, and the persistence of those weeds may be enhanced as the result of gene flow. Therefore, 'a full understanding of the combined effect of these forces on the fitness of an escaped transgene may not be apparent without the context of the complete ecological community' (p. 4) ${ }^{58}$.

Risks of gene flow between GE corn and soybeans and their wild relatives are nil because neither GE crop has wild or weedy relatives in the USA. Gene flow issues with GE cotton are also of limited concern because the spatial overlap between the crop and its relatives is not extensive. However, gene flow risks could change in the future if GE crops are commercialized for other species that have the 
capability of interbreeding with related species, such as alfalfa, sunflowers or creeping bent grass. It could also change as GE crops are adopted more widely in developing countries where domesticated crops do have wild relatives. This could have consequences for weed management strategies. In addition to gene flow into weedy relatives, gene flow of legal GE traits into non-GE varieties of the same crops (known as 'adventitious presence') is also a serious issue, but more for economic and social than environmental reasons. For example, if organic growers have GE content in their crops above private market or government thresholds, they could lose access to those markets.

The short-term future of GE crop development appears to be in the genetic engineering of crops with multiple 'stacked' traits. First released in 2007, multiple trait crops, usually with a combination of Bt and HR mechanisms, were the fastest growing group of GE crops between 2007 and 2008 , experiencing $66 \%$ growth $^{59}$. Such crops may be a double-edged sword. While they give growers a newer arsenal of products to avoid resistance problems, they also make the challenge of understanding the broader ecological impacts, including resistance development and gene flow, even more complex. In addition, these developments appear to continue to be limited to mainstream crops. The development of GE options for minor crops, or traits that address specific environmental and ecological issues, does not appear to be rapidly forthcoming as university research on GE crops tends to mirror industry research profiles ${ }^{60}$.

\section{Economic Impacts}

Assuring the economic viability of the farm operation, as well as for related businesses and their employees, is a central principle of sustainable agriculture. It is clear from the extensive adoption of GE soybean, cotton and corn varieties in the USA that the perceived benefits to adopting farmers generally outweigh any short-run economic costs, including the technology fees. However, the economic impacts, both benefits and costs, associated with GE crops can transcend the farmers using the technology to those down the supply chain, such as livestock producers, and to non-adopters. Moreover, these economic effects will change as new GE crop technologies emerge and are adopted in the USA and abroad.

GE crops can affect farmers' economic situations in different ways depending on the particular technology trait adopted. For example, the use of IR crops has generally had a positive impact on yields and reduced some production expenses, especially for farmers adopting $\mathrm{Bt} \operatorname{cotton}^{61,62}$. However, the use of HR crops does not appear to have increased yields significantly but rather conferred other benefits such as reduced production expenses and more flexibility and time savings for farm operators that facilitate off-farm employment ${ }^{63,64}$.

Although not usually counted as an economic gain, farmers adopting GE crops have experienced increased safety, from handling less toxic compounds, and greater flexibility in farm operations than farmers using conventional non-GE cropping systems ${ }^{65-68}$. Further, there is some early evidence that the newer stacked traits result in less yield variability and thereby provide risk management value to the adopting farmers.

Offsetting some of the cost savings and any yield advantages are the technology fees that farmers must pay to access the seed technology. Due to the proprietary nature of fee data, peer-reviewed evidence that analyzes the level, variation and trends in these costs by crop and over time is rare. Aggregate data on seed prices show that their increase has exceeded the rate for all agricultural inputs by $30 \%$ since the introduction of GE seeds in $1996^{69,70}$. Given the high present rates of adoption of GE crops in the USA, it appears safe to conclude that the technology fees and contract restrictions are not deterring broad use to this point.

A second economic disadvantage of the widespread global adoption of GE crops would occur if the increased supplies put downward pressure on prices received for corn, cotton and soybean and therefore on the incomes of all farmers growing those crops, assuming undifferentiated markets for GE and non-GE crops. Anecdotal stories suggest that this may already be occurring for US cotton growers (GE and non-GE) because of large increases in GE cotton production in China and India. There is a lack of concrete evidence to judge how significant this economic impact might be on adopters and non-adopters. Other agricultural supply system parties should, in theory, benefit from such increased supplies and lower prices. For example, livestock producers should pay lower feed costs, all else equal, and consumers who purchase retail food products made with the GE crop ingredients should pay less as well. Unfortunately, virtually no peer-reviewed evidence exists to place credible values on the impacts on livestock producers and consumers.

Because of agricultural market linkages, the decisions of GE crop adopters affect the input prices and options for both farmers who use products made with GE ingredients and those who choose not to grow GE crops or who do not have that option available. Again, virtually no peerreviewed evidence exists to analyze the potential economic repercussions on non-adopters who choose not to use GE technology for ideological or other reasons.

A number of other economic impacts can be anticipated in theory but also have not been documented. For example, pecuniary externalities likely are not limited to the cost and availability of inputs. If GE technology successfully reduces pest pressure on a field, farmers of adjacent or nearby fields in the agricultural landscape planted with nonGE crops may benefit via lower pest control costs associated with reduced pest populations. However, nonadopters of GE technology could suffer from the development of weeds and insects with pesticide resistance in neighboring fields planted with GE crops. When this happens, non-GE farmers may have to resort to managing 
the resistant pests with additional, potentially more toxic or more expensive forms of control, even though their practices may not have led to the emergence of resistance.

Inadvertent gene flow from GE to non-GE varieties of crops can increase production costs through crosspollination between GE and non-GE plants from different fields, co-mingling of GE seed with non-GE seed, and germination of seeds left behind (i.e., volunteers) following the production year. Similarly, if future GE commercial traits cross into weedy relatives, weed control expenses will be higher for all fields onto which these weeds spread, whether the farmer grows GE crops or not. As mentioned under environmental impacts, gene flow of GE traits into organic crops may jeopardize some organic crop farmers' harvest by rendering their output unacceptable for highvalue domestic and foreign markets. The extent of this impact has not been documented to our knowledge.

\section{Social Impacts}

Heffernan $^{71}$ and others ${ }^{72,73}$ have argued that large agribusinesses appear to have gained monopolistic and oligopolistic control of agricultural input and commodity markets, enabling them to extract greater profits at the expense of farmers and to exert greater political influence. Concentration has increased since the late 1970s and early 1980s, when the enforcement of antitrust regulations was relaxed. Regulators sought to 'balance the efficiency gains from concentration with the inefficiencies associated with possible anti-competitive behavior...' (p. 553) $)^{74}$. This change was influenced by the Chicago School's 'belief that most markets are competitive, even if they contain a relatively few number of firms' (p. 556) ${ }^{74}$. Heffernan and Constance $^{75}$ credit the weaker enforcement of antitrust regulations in the agri-food system with the rise of corporate consolidation. Heffernan ${ }^{71,76}$ further contends that a small group of agribusinesses have achieved oligopolistic control of commodity value chains. For example, four firms control over $80 \%$ of beef packing, over $60 \%$ of pork packing and $80 \%$ of soybean crushing. Just three firms control $55 \%$ of flour milling.

As seeds became the mechanism for agricultural biotechnology firms to deliver their intellectual property to agricultural raw material producers, horizontal consolidation of intellectual property in the agricultural biotechnology sphere gave way to vertical consolidation throughout the agri-food system ${ }^{77,78}$. Hendrickson and Heffernan ${ }^{76}$ cite secondary sources describing how a few companies that had significant holdings of intellectual property began purchasing seed companies. Two companies, DuPont-Pioneer and Monsanto, account for $56 \%$ of the US seed corn market ${ }^{79}$. Globally, four companies account for $29 \%$ of the world market in commercial seeds ${ }^{80}$. Since Monsanto's seeds account for $90 \%$ of the world's genetically modified crop acreage, there is a strong likelihood that they have secured a near monopoly in those markets ${ }^{81}$.
Glenna and Cahoy ${ }^{82}$ analyzed concentration of patent ownership in GE corn and GE non-corn plants. They found that there are 37 discrete owners of the $525 \mathrm{GE}$ corn patents and 118 discrete owners of the $1013 \mathrm{GE}$ non-corn patents. These initial data indicate that multiple companies have intellectual property holdings of GE plants. However, a closer analysis of changing ownership, due to mergers and joint ventures, indicates that the top three firms in the GE corn category control $85.0 \%$ of the patents, and the top three firms in the GE non-corn category control $69.6 \%$ of patents. These findings indicate that there is substantial concentration of ownership of the intellectual property associated with these transgenic crops. That degree of concentration could affect the portfolio of GE and non-GE cultivars available to farmers who wish to pursue conventional and sustainable agriculture practices. In addition to the question of whether such concentration will reduce economic returns to farmers, which would affect the ability of farmers to pay living wages to their employees, this question of control is also linked to the question of what decisions are made regarding the further development of this technology.

One of the key, and arguably the central, tenants of sustainable development related to social dimensions is that it should be participatory, drawing on contributions from all stakeholders in the system in question. For the most part, the development of GE technology has not incorporated farmers and users of these crops as participants, except as firms conduct focus groups or grower meetings to test market demands for new products. Farmers are generally thought of as 'adopters' whose role is to purchase and use a technology developed off-farm. It is reasonable to further hypothesize that the comparative lack of development of new types of GE technologies in minor crops, to address the full suite of ecological problems, and to enhance nutritional quality for those who eat these products, are due in part to limited participation in the technological development process by affected actors. As a first step in this direction, participator crop breeding programs, as well as those that are committed to open-source breeding, offer opportunities to make the biotechnology development process more collaborative and thus more sustainable, than the current research structure. This possibility will be discussed in more detail later in this manuscript.

\section{Trends in Public Research}

One of the reasons that sustainable agriculture proponents have been skeptical of GE crops, even those emerging from universities, is that university research has been seen as favoring large agribusinesses and large farmers ${ }^{10,83-89}$ and has neglected public goods ${ }^{38}$. The division of labor that has emerged for agricultural biotechnology research and development is often characterized as consisting of public-sector and private-sector research institutions. Private-sector institutions, such as agribusinesses, tend to focus on major crop varieties and other crops, which are likely to 
be planted in volumes that will generate sufficient revenue to cover R\&D, regulatory and manufacturing costs and earn a profit. In contrast, public-sector institutions, such as universities, are expected to conduct research on crops that may be deemed valuable for society, even though their limited scale might not be profitable in a financial sense ${ }^{90}$. However, policies directed at promoting universityindustry biotechnology research collaborations may be blurring this division of labor and impacting the potential of agricultural biotechnology to address socio-economic challenges.

Although the intellectual property protection that accompanies GE crops has inspired the private sector to invest in agricultural research, those investments have overwhelmingly been targeted at plants and traits that are of interest to the largest farms with the most widely planted crops $^{91}$. The two dominant commercialized traits, HR and IR, were developed to realize a return on substantial R\&D investments for agri-biotechnology firms as they sought to switch from a chemical pesticide approach to a life science regime ${ }^{92}$. These traits additionally fit easily within the firms' established and, therefore, familiar approaches to pest management ${ }^{93}$. The FAO (p. 35) ${ }^{91}$ points out that concern that many fruit, vegetable and specialty crops will be neglected is supported by the evidence from field trials of transgenic crops in industrialized nations. Concerns have been raised that university collaborations with agribusinesses to conduct transgenic crop research is shifting the focus of universities toward more private-sector research interests $^{94}$. To evaluate the validity of this concern, Welsh and Glenna ${ }^{95}$ examined applications for transgenic crop field trials over time. They found that university research on transgenic crops has increasingly mirrored the research profile of for-profit firms. The implication is that over time fewer resources will be devoted by universities to GE technologies for minor and specialty crops that do not have the potential for turning a profit. In a related national study of academic scientists conducting research related to agricultural biotechnology, Buccola et al. ${ }^{96}$ found that federal and state research support encourages more basic research, whereas industry and foundations support more applied research in US universities, and that downstream (i.e., more applied) research tends to be legally and economically more excludable than upstream (i.e., more basic) research. They conclude that publicly funded research offers the highest potential for achieving public goods, such as the basic science of genetic mechanisms, broadly accessible platform technologies and non-market environmental services ${ }^{96}$.

\section{Countertrends in Public Research}

Until this point, we have presented evidence that suggests that the majority of GE crop development has not been well integrated into an approach that supports all facets of sustainable agriculture. However, the early pattern of GE development does not necessarily preclude that outcome.
There is nothing inherent in the technology that connects it to major crops for large-scale farming and agribusiness at the expense of minor crops, small farms, public environmental issues and developing countries. As we noted earlier, Naylor et al. ${ }^{11}$ contend that a variety of techniques often referred to as biotechnologies could be applied to improving minor crops in developing countries, even though orphan crops and developing countries have been largely ignored in the first generation of GE crop research and development. Public research institutions, research funding and intellectual property policies, for example, could be re-designed to promote applications that are conducive to sustainability.

Therefore, we want to analyze some processes that might be conducive to developing and commercializing GE crops consistent with the principles of sustainable agriculture. Part of the challenge is to consider what social and economic contexts might be most conducive to fostering such a process. If the current trends in agricultural research on transgenic crops are shifting public research organizations toward private-interest research goals, which prioritize the needs of the conventional industrial agricultural system, then we are led to ask how those research and technology development processes would need to be altered to allow for further progress on sustainable agriculture.

As noted earlier, the interests of small, sustainable and organic farmers have received little attention from universities and firms, which have increasingly focused on the needs of larger agricultural operations that are more integrated within an industrialized agri-food system model ${ }^{10,84-89}$. Studies often emphasize that the land-grant university system has generally been supportive, from a structural perspective, of conventional agriculture, making it necessary for farmers interested in organic and more sustainable agriculture to conduct their own research and to share the information through interactions with other farmers ${ }^{84,88}$. Farmers recognize that there may be local social, economic and ecological conditions that can best be addressed through conversations with others who are dealing with the same conditions ${ }^{84,86-88}$.

Some supplemental approaches for crop improvement and seed development exist. These approaches include participatory plant breeding, evolutionary-participatory plant breeding, or decentralized plant breeding ${ }^{97-99}$. Although details often vary with the labels, these approaches nearly always involve professional plant breeders, either university or international crop improvement center employees, working together with farmers to develop new plant varieties. Participatory plant breeding emerged primarily to address developing world issues, but efforts have been made to bring this approach to organic farming in the USA. Although the participatory programs operating in developing countries tend not to explicitly serve organic farmers, they do serve low-input farmers whose use of agricultural chemicals and fertilizers is often similar to the approaches used by organic farmers ${ }^{97-99}$. Although we are unaware of the number and variety of 
participatory breeding programs currently operating in the USA, we highlight two cases to illustrate how such programs could incorporate the use of agricultural biotechnologies to help promote sustainability.

One study of a participatory plant breeding program in the northeastern USA highlights the structural changes in agricultural research, which are needed to better support sustainable agriculture. Mendum and Glenna ${ }^{100}$ refer to this program as the Seed Project, a collaborative effort between university researchers, small organic seed companies and organic farmers to develop new varieties of organic crops. Several factors make this program novel. First, the university scientists and the farmers involved in the collaboration acknowledged that universities have largely ignored small-scale fruit and vegetable farmers. Furthermore, the university scientists conscientiously rebuilt relationships with such farmers. Second, the farmers became actively involved in the research and development of new seed varieties. For example, through regular meetings and networking, farmers provided information to participating breeders about northeastern US organic conditions, their specific breeding goals, as well as the results of on-farm seed trials and breeding goals. Thus, research was directed more at solving problems that farmers face in diverse environments than at breeding for homogeneous environments or at achieving the goals of capital accumulation of large agribusinesses. Because small organic farmers often sell directly to consumers, the collaboration with small farmers also served indirectly to integrate consumer interest into the breeding process. Third, to accommodate the inclusion of small seed companies into the collaboration, the university created a simplified and streamlined intellectual property transfer agreement. The university maintained control of the intellectual property, even if the germplasm came from the private sector. And the university charged a standardized small (5\% of profit) licensing fee for a company or farm that developed and sold resulting seed. By retaining control and charging a small fee, the university could ensure that germplasm would remain publicly available while generating revenue to support the program. Fourth, university researchers, seed companies and farmers worked together to re-establish the seed processing machinery and expertise and other basic small-farming infrastructure that is needed to sustain small-scale farming.

It is important to emphasize the contributions that stakeholders bring to such a participatory breeding program. Mendum and Glenna ${ }^{100}$ point out that, without the university breeding program, farmers and small seed companies lack technical expertise and access to germplasm. Farmers and seed company breeders need access to disease resistance and other features that can be found in research collections. Those collections reflect adaptations crafted by earlier generations of both farmers and breeders. However, those materials are not widely accessible. Without skilled intervention and broad access to genetic material, organic farmers are at undue risk for crop failure.
Farmers and others have difficulty collecting the material they need because it is owned by others or because collection work is expensive and involves travel, storage and benefits from expert analysis. Small regional seed companies also lack the time and money to breed enough to fill the increasing demands. Moreover, farmers need training to ensure that they maintain varietal integrity. Such training is especially important for organic farmers entering the profession with no previous farming experience.

The farmers also have made important contributions to the project. One key contribution was to encourage the plant breeders to promote agricultural biodiversity. Because the farmers mostly sold to local markets, farmers repeatedly mentioned the need for organic seeds to meet the tastes and interests of their consumers. Since the culinary interests of consumers were being represented by the farmers, there was an incentive to seek diverse plant characteristics responsive to markets. One could also envision ways to integrate the consumers' interests in nutrition and other health concerns into this participatory process.

Farmers representing diverse consumers and diverse ecological conditions serve to expand the ecological and social frames of plant breeding programs. Farmers are also able to inject their social and economic interests into the research endeavor. As a result, the Seed Project conforms to the sustainable agriculture paradigm that Lyson ${ }^{4}$ contrasts with the conventional paradigm. Within such a participatory breeding context, it is not inconceivable that a plant breeder could utilize agricultural biotechnology techniques to conduct research and to develop new varieties that would be conducive to sustainability principles.

Washington State University's effort to develop perennial wheat is another model worth considering. If the project unfolds as planned, farmers would need to plant the wheat every 3 to 5 years, which would greatly reduce the farmers' need to purchase seeds each year and would reduce the time spent planting wheat. The breeders who are involved seek to develop participatory relationships between farmers and breeders to develop low-input and organic wheat varieties, which hold the potential to reintroduce farmers to seed selection skills and enable farmers to retain a greater share of profits from the production process ${ }^{97}$. Washington State wheat breeders began developing participatory breeding pilot projects with farmers in 2003 to work with farmers in diverse farming systems and microclimates to develop new wheat varieties $^{101}$. The effort is significant for at least two reasons. First, the goals of low off-farm input levels and breeding for heterogeneous environments are conducive to the principle of ecological sustainability. Second, this project also is addressing issues of farmer control of inputs, which can lead to improved profitability, which addresses equity as well as economic sustainability principles.

Like the Seed Project, the perennial wheat project reflects a change in the dominant social relations of agricultural research and represents a shift away from what 
Lyson $^{4}$ refers to as the conventional and toward the sustainable agricultural paradigm. Although the Washington State breeders involved in the perennial breeding project have not expressed an interest in using agricultural biotechnology, it is conceivable that biotechnological techniques could be useful in this sustainability paradigm for crop improvement.

Before holding these models up as potentially transformative, and considering the role that agricultural biotechnology could play in such a transformation, it is important to consider two obstacles. First, problem-solving approaches to agricultural research are not typically funded within the existing competitive grant funding system. Huffman et al. ${ }^{102}$ describe how the shift from formula funding to competitive funding privileges short-term, cutting-edge research that is defined as important at the national level, as opposed to long-term research projects directed at solving state-level problems. Mendum and Glenna $^{100}$ explain that the breeders involved in the Seed Project had to be very creative to generate a fundable proposal. They succeeded in getting funding for two rounds, but, were unable to get a third round of funding. Second, agricultural biotechnology research tends to involve issues of intellectual property ${ }^{4}$. Even if universitybased scientists were to use agricultural biotechnological techniques within a sustainability paradigm to develop crops to address problems that farmers face, breeders might still face patenting and licensing issues that would limit their use.

\section{Broader Structural Change}

The participatory breeding programs and other innovative efforts to develop GE seed technologies that support sustainable agriculture principles provide models that could inform regional and national scale programs. However, realistically, they are only small steps toward the larger reforms that appear to be needed to enhance the compatibility of biotechnology with sustainable agriculture. The larger shifts will not flourish without a significant change in the structure of the political-economy and the public and private institutions that govern agricultural biotechnology research and technology development. An example might be the creation of novel intellectual property institutions that foster low-cost access to genetic material for GE plant development by public researchers ${ }^{103}$. Another might be a differentiated and targeted regulatory approach to GE-crop trait development and commercialization that meets human and environmental safety standards while minimizing unnecessary delay and expense ${ }^{104}$. Hubbell and Welsh $^{34}$ explore potential institutional changes such as including communal property rights regimes for plant genetic material and biotechnology industry structural reforms. We do not have space to explore such changes in detail, but offer three principles that should guide the development of the reform framework.
The first tenet is to combine frontier intellectual science with the latest experiential knowledge to solve complex (i.e., non-reductionist) problems ${ }^{105}$. In other words, the successful application of biotechnology to further sustainable agricultural systems will not come from scientists toiling alone in their laboratories. Our two examples of participatory plant breeding illustrate this point. The USDA's Sustainable Agriculture Research and Education (SARE) program has encouraged such a collaborative approach to develop innovations that fit the needs of holistic farming systems. However, bioscientists working on GE crop developments likely have not been viewed as potential collaborators in sustainable agriculture projects. The incorporation of socio-economic equity elements into agricultural biotechnology R\&D programs should help foster alliances between the two groups. For example, if GE crop innovations help reduce reliance on external inputs by small farmers, trust will be enhanced.

A second guiding principle is to involve all relevant stakeholders in a collaborative process to assure their values and needs are integrated into the search for solutions. While the participatory plant breeding efforts bring farmers, seed companies and plant researchers together, wider collaboration could help expand such efforts. Consider, for example, which groups have a stake in innovations that could enhance the nutritional quality of foods, increase ecosystem service provision and improve renewable energy feedstocks, while stabilizing and increasing farm income. Those parties extend well beyond farmers, plant scientists and seed developers, to food processors and retailers, health care professionals, conservation groups, government environmental and energy programs and consumer interest associations. Opening up a broad dialogue with such groups would build support both for sustainable agriculture and biotechnology $R \& D$ programs that meet their needs.

The final principle is that biotechnology innovations that can deliver public goods will receive underinvestment by the private market ${ }^{106}$. This tenet stems from the nonrival and non-exclusive traits of public goods that prevent companies from capturing enough returns in markets to supply all such innovations with positive net social benefits. Examples include plants that produce some of their own nutrient requirements, e.g., nitrogen, thereby reducing polluted runoff, and plants with improved nutritional qualities that lower demands on the public health care system. Many companies involved in GE crop development are already working on commercializing new traits that provide both private (farmer) and some public benefits, such as drought tolerance that could lessen water demands. However, the inability of farmers to capture benefits beyond their farm boundaries means that the companies will not invest sufficiently in such technologies. Some form of public or other collective support that is geared toward enhancing public goods will be needed to exploit the full potential of agricultural biotechnology in fostering a more sustainable agriculture. 


\section{Conclusion}

The primary objective of our paper has been to address the question of whether the goals and practices of sustainable agriculture are fundamentally incompatible with the development and deployment of agricultural biotechnology. Our central argument has been that to answer this question it is necessary to move beyond analyses of whether agricultural biotechnology is currently helping conventional agricultural production become more sustainable from strictly ecological or economic dimensions. Conceptualizations of sustainable development emphasize the integration of multiple dimensions in a systemic fashion, including social effects, and in a manner that is participatory in character among all relevant stakeholders. We recognize that reducing toxic agricultural chemical use brings benefits to the physical environment and human health, and often increases economic returns. While these are valuable improvements to the farmer, they remain just a first step toward achieving a more sustainable agriculture.

Proponents of agricultural biotechnology tend to focus on the potential for agricultural biotechnology to address specific problems associated with production aspects of agriculture, such as soil loss, increasing yields and reducing economic production costs. Opponents focus on how the technology is not only the product of a particular politicaleconomic structure but also fails to address issues of maldistribution of power and inequity within and across societies. This distinction is relevant because sustainability is a concept driven by equity concerns. Not only did early discussions of sustainability emphasize intergenerational equity objectives, i.e., fairness to future generations, but sustainability science now recognizes the need to also address intragenerational equity concerns. For that reason, amongst other equity issues, it has to take into consideration the political-economic structures and the distribution of power and equity within and across generations.

We do not believe that agricultural biotechnology should be rejected categorically as a potential tool to further sustainable agriculture. Such a position would amount to rejecting a powerful biological science tool to address critical challenges in food production, energy transformations and a plethora of environmental challenges. Indeed, such a rejection could precipitate important inequities inside and outside agriculture. A few promising recent developments suggest that agricultural biotechnology can contribute to sustainable agriculture ${ }^{3}$. However, significant changes need to occur in the political-economic support structure and institutions of agricultural research and development before biotechnology products could address the full suite of ecological, economic and social (equity) principles that should guide the development of sustainable agriculture systems. Overcoming the obstacles to such reforms will require innovative collaborations of farmers with government, non-profit, industry, consumer and university stakeholders. Without the participation of all parties and a significant public commitment to delivering public goods, the question of how compatible agricultural biotechnology is with sustainable agriculture will remain unanswered.

Acknowledgements. We are indebted to Rick Welsh for the invitation to write this paper and for his insightful review comments on an earlier draft. We are also grateful for valuable review comments by Jill Auburn. Ervin and Jussaume served on a National Research Council (NRC) Committee during 20092010 that studied the impacts of GE crops on farm sustainability in the US and benefited from the insights and contributions on this topic by other Committee members and NRC staff. Despite this valuable assistance from so many, only the authors are responsible for the content of this article. We also wish to thank Kristal Jones who did excellent yeoman work in helping us meet the RAFS guidelines.

\section{References}

1 Brookes, G. and Barfoot, P. 2008. GM Crops: Global SocioEconomic and Environmental Impacts 1996-2006. PG Economics Ltd, Dorchester, UK.

2 Scientific American. 2009. Biotech's plans to sustain agriculture. Scientific American 301(4):86-94.

3 Cavatorta, J.R., Gray, S.M., and Jahn, M. 2010. Transgenic virus resistance in plants - a sustainable alternative. In J. Popp, M. Jahn, M. Matlock, and N. Kemper (eds). The Role of Biotechnology in a Sustainable Food Supply. Cambridge University Press, New York, forthcoming.

4 Lyson, T.A. 2002. Advanced agricultural biotechnologies and sustainable agriculture. Trends in Biotechnology 20(5):193-196.

5 Ronald, P. 2008. The New Organic. The Boston Globe, March 16. Available at Web site http://www.boston.com/ bostonglobe (accessed 18 March 2010).

6 Ronald, P. and Adamchak, R. 2008. Tomorrow's Table: Organic Farming, Genetics, and the Future of Food. Oxford University Press, New York.

7 Nelson, G.C. and DePinto, A. 2001. GMO adoption and nonmarket effects. In G.C. Nelson (ed.). Genetically Modified Organisms in Agriculture: Economics and Politics. Academic Press, San Diego, CA.

8 Burros, M. 2000. U.S. Planning Tough Rules for Growing Organic Food. New York Times, March 4. Available at Web site http://www.nytimes.com (accessed 18 March 2010).

9 Kaufmann, M. 2000. New Organic Rules Ban GE. The Washington Post, March 4. Available at Web site http:// www.washingtonpost.com (accessed 18 March 2010).

10 Jussaume, R.A. Jr and Glenna, L. 2009. Considering structural, individual and social network explanations for ecologically sustainable agriculture: an example drawn from Washington State wheat growers. Sustainability 1:120-132.

11 Naylor, R.L., Falcon, W.P., Goodman, R.M., Jahn, M.M., Sengooba, T., Tefera, H., and Nelson, R.J. 2004. Biotechnology in the developing world: a case for increased investments in orphan crops. Food Policy 29:15-44.

12 Avery, D.T. 1995. Saving the Planet with Pesticides and Plastic: The Envrionmental Triumph of High-Yield Farming. Hudson Institute, Indianapolis, IN.

13 Scott, D. 2005. The magic bullet criticism of agricultural biotechnology. Journal of Agricultural and Environmental Ethics 18(3):259-267. 
14 Burrows, B. 2002. Biodiversity and biotechnology. In V. Shiva and G. Bedi (eds). Sustainable Agriculture and Food Security: The Impact of Globalization. Sage Publications, New Delhi. p. 396-406.

15 Altieri, M.A. and Rosset, P. 2002. Ten reasons why biotechnology will not ensure food security, protect the environment, or reduce poverty in the developing world. In R. Sherlock and J.D. Morrey (eds). Ethical Issues in Biotechnology. Rowman and Littlefield, Lanham, MD. p. $175-182$.

16 Rissler, J. and Mellon, M. 1996. The Ecological Risks of Engineered Crops. MIT Press, Cambridge, MA.

17 Benbrook, C. 2009. Impacts of Genetically Engineered Crops on Pesticide Use: The First Thirteen Years. The Organic Center. Available at Web site http://www.organic-center.org (accessed 18 March 2010).

18 Thro, A.M. 2004. Europe on transgenic crops: how public plant breeding and eco-transgenics can help in the transatlantic debate. AgBioForum 7(3):142-148.

19 Lacy, W.B., Glenna, L., Biscotti, D., and Welsh, R. 2009. Agricultural biotechnology, socioeconomic effects, and the fourth criterion. In A. Seidel (ed.). Wiley Encyclopedia of Industrial Biotechnology. John Wiley and Sons, New York, forthcoming.

20 Allen, P. 2004. Together at the Table: Sustainability and Sustenance in the American Agrifood System. Penn State University Press, University Park, PA.

21 Kleinman, D.L. and Kinchy, A.J. 2003. Boundaries in science policy making: bovine growth hormone in the European Union. The Sociological Quarterly 44(4):577-595.

22 Reed, M. 2002. Fight the future! How the contemporary campaigns of the UK organic movement have arisen from their composting of the past. Sociologia Ruralis 41(1):131-145.

23 Pfeffer, M. 1992. Sustainable agriculture in historical perspective. Agriculture and Human Values 9(4):4-11.

24 National Research Council. 2003. Frontiers in Agricultural Research: Food, Health, Environment, and Communities. National Academies Press, Washington, DC.

25 Sen, A. 1999. Development as Freedom. Anchor Books, New York.

26 Bell, S. and Morse, S. 2006. Measuring Sustainability: Learning from Doing. Earthscan Press, London.

27 Gold, M.V. 2009. Sustainable Agriculture: Information Access Tools. US Department of Agriculture, Alternative Farming Systems Information Center. Available at Web site http://www.nal.usda.gov (accessed 18 March 2010).

28 Harwood, R. 1990. A history of sustainable agriculture. In C.A. Edwards, R. Lal, P. Madden, R.H. Miller, and G. House (eds). Sustainable Agricultural Systems. Soil and Water Conservation Society, Ankeny, IA. p. 3-19.

29 Harris, J.M. 2006. Environmental and Natural Resource Economics. 2nd ed. South Western College, Florence, KY.

30 Pearce, D. and Barbier, E. 2000. Blueprint for a Sustainable Economy. Earthscan Press, London.

31 Daly, H.E. 1994. Beyond Growth: The Economics of Sustainable Development. Beacon Press, Boston, MA.

32 Carrière, Y., Sisterson, M.S., and Tabashnik, B.A. 2004. Resistance management for the sustainable use of Bacillus thuringiensis in integrated pest management. In A.R. Horowitz and I. Ishaaya (eds). Insect Pest Management: Field and Protected Crops. Springer-Verlag, Berlin, Heidelberg. p. 65-95.
33 Welsh, R., Hubbell, B., Ervin, D., and Jahn, M. 2002. GM crops and the pesticide paradigm. Nature Biotechnology 20(6):548-549.

34 Hubbell, B. and Welsh, R. 1998. Transgenic crops: engineering a more sustainable agriculture? Agriculture and Human Values 15:43-56.

35 Baum, J.A., Bogaert, T., Clinton, W., Heck, G.R., Feldmann, P., Ilagan, O., Johnson, S., Plaetinck, G., Munyikwa, T., Pleau, M., Vaughn, T., and Roberts, J. 2007. Control of coleopteran insect pests through RNA interference. Nature Biotechnology 25(11):1322-1326.

36 USDA-NASS. 2009. Acreage. US Department of Agriculture, National Agricultural Statistics Service, Cr Pr 2-5. Available at Web site: http://usda.mannlib.cornell.edu (accessed 18 March 2010).

37 James, C. 2008. Global Status of Commercialized Biotech/ GM Crops: 2008. ISAAA, Brief No. 39 ed. ISAA, Ithaca, New York. Available at Web site http://www.isaaa.org (accessed 18 March 2010).

38 Ervin, D., Welsh, R., Batie, S., and Carpentier, C.L. 2003. Towards an ecological systems approach in public research for environmental regulation of transgenic crops. Agriculture, Ecosystems and the Environment 99:1-14.

39 Wolfenbarger, L. and Phifer, P. 2000. The ecological risks and benefits of genetically engineered plants. Science 290:288-293.

40 Fernandez-Cornejo, J., Nehring, R., Sinha, E.N., Grube, A., and Vialou, A. 2009. Assessing recent trends in pesticide use in U.S. agriculture. Presented at the Annual Meeting of the Agricultural and Applied Economics Association (AAEA). 26-28 July 2009, AAEA, Milwaukee, WI. Available at Web site: http://purl.umn.edu/49271 (accessed 18 March 2010).

41 Fernandez-Cornejo, J. and Caswell, M.F. 2006. The First Decade of Genetically Engineered Crops in the United States. US Department of Agriculture, Economic Research Service, Economic Information Bulletin No. 11. USDA, Washington, DC. Available at Web site: http://purl.access. gpo.gov (accessed 18 March 2010).

42 Carrière, Y., Ellers-Kirk, C., Sisterson, M.S., Antilla, L., Whitlow, M., Dennehy, T.J., and Tabashnik, B.E. 2003. Long-term regional suppression of pink bollworm by Bacillus thuringiensis cotton. Proceedings of the National Academy of Sciences of the United States of America 100(4):1519-1523.

43 Tabashnik, B.E., Gassmann, A.J., Crowder, D.W., and Carrière, Y. 2008. Field-evolved resistance to $B t$ toxins. Nature Biotechnology 26(10):1074-1076.

44 Tabashnik, B.E., Van Rensburg, J.B.J., and Carrière, Y. 2009. Field-evolved insect resistance to Bt crops: definition, theory, and data. Journal of Economic Entomology 102(6):2011-2025.

45 Fernandez-Cornejo, J. and McBride, W.D. 2002. Adoption of bioengineered crops. US Department of Agriculture, Economic Research Service, Agricultural Economic Report No. 810. Available at Web site http://www.ers.usda.gov (accessed 18 March 2010).

46 Cerdeira, A.L. and Duke, S.O. 2006. The current status and environmental impacts of glyphosate-resistant crops: a review. Journal of Environmental Quality 35(5):1633-1658.

47 Frisvold, G., Boor, A., and Reeves, J.M. 2007. Simultaneous diffusion of herbicide tolerant cotton and conservation tillage. In Proceedings of the Beltwide Cotton Conference, 
12 January 2007, National Cotton Council of America, New Orleans, LA.

48 Mensah, E.C. 2007. Economics of Technology Adoption: A Simple Approach. VDM Verlag Dr. Müller, Saarbrücken, Germany. Available at Web site: http://deposit.d-nb.de (accessed 18 March 2010).

49 Roberts, R.K., English, B.C., Gao, Q., and Larson, J.A. 2006. Simultaneous adoption of herbicide-resistance and conservation-tillage cotton technologies. Journal of Agricultural and Applied Economics 38(3):629-643.

50 Zelaya, I.A. and Owen, M.D.K. 2000. Differential response of common waterhemp (Amaranthus rudis) to glyphosate in Iowa. In Proceedings of the Weed Science Society of America. Weed Science Society of America, Toronto, Canada. p. 62-63.

51 Culpepper, A.S., Grey, T.L., Vencill, W.K., Kichler, J.M., Webster, T.M., Brown, S.M., York, A.C., Davis, J.W., and Hanna, W.W. 2006. Glyphosate-resistant Palmer amaranth (Amaranthus palmeri) confirmed in Georgia. Weed Science 54(4):620-626.

52 Culpepper, A.S. and York, A.C. 2007. Glyphosate-resistant Palmer amaranth impacts southeastern agriculture. In Proceedings of the Illinois Crop Protection Technology Conference. University of Illinois Urbana-Champaign, Champaign, IL. Available at Web site http://ipm.illinois.edu (accessed 18 March 2010).

53 Legleiter, T.R. and Bradley, K.W. 2008. Glyphosate and multiple herbicide resistance in common waterhemp (Amaranthus rudis) populations from Missouri. Weed Science 56(4):582-587.

54 Dauer, J.T., Luschei, E.C., and Mortensen, D.A. 2009. Effects of landscape composition on spread of an herbicide resistant weed. Landscape Ecology 24(6):735-747.

55 Mortensen, D.A., Egan, J.F., Smith, R.G., and Ryan, M. 2009. Unintended consequences of stacking herbicide tolerance traits in soybean. Presented at Working Landscapes, the Annual Meeting of the Society for Range Management, 7-10 February 2010, SRM, Denver, CO. Available at Web site http://www.srm.org (accessed 18 March 2010).

56 Ellstrand, N.C. 2001. When transgenes wander, should we worry? Plant Physiology 125(4):1543-1545.

57 Ellstrand, N.C. 2003. Going to 'great lengths' to prevent the escape of genes that produce specialty chemicals. Plant Physiology 132(4):1770-1774.

58 Sasu, M.A., Ferrari, M.J., Du, D., Winsor, J.A., and Stephenson, A.G. 2009. Indirect costs of a nontarget pathogen mitigate the direct benefits of a virus-resistant transgene in wild Cucurbita. Proceedings of the National Academy of Sciences of the United States of America 106(45):19067-19071.

59 James, C. 2008. Global Status of Commercialized Biotech/ GM Crops. ISAAA, Ithaca, NY. Available at Web site http:// www.isaaa.org (accessed 18 March 2010).

60 Welsh, R. and Glenna, L. 2006. Considering the role of the university in conducting research on agri-biotechnologies. Social Studies of Science 36(6):929-942.

61 Piggott, N.E. and Marra, M.C. 2007. The net gain to cotton farmers of a natural refuge plan for Bollgard II ${ }^{\circledR}$ Cotton. AgBioForum 10(1):1-10.

62 Siebert, M.W., Nolting, S., Leonard, B.R., Braxton, L.B., All, J.N., Van Duyn, J.W., Bradley, J.R., Bacheler, J., and
Huckaba, R.M. 2008. Efficacy of transgenic cotton expressing CrylAc and CrylF insecticidal protein against heliothines (Lepidoptera: Noctuidae). Journal of Economic Entomology 101(6):1950-1959.

63 Fernandez-Cornejo, J., Hendricks, C., and Mishra, A.K. 2005. Technology adoption and off-farm household income: the case of herbicide-tolerant soybeans. Journal of Agricultural and Applied Economics 37(3):549-563.

64 Smith, K.R. 2002. Does off-farm work hinder 'smart' farming? US Department of Agriculture, ERS, Agricultural Outlook, AGO-294. USDA, Washington, DC. 28-30.

65 Ahmad, A., Wilde, G.E., Whitworth, R.J., and Zolnerowich, G. 2006. Effect of corn hybrids expressing the coleopteranspecific Cry3Bb1 protein for corn rootworm control on aboveground insect predators. Journal of Economic Entomology 99(4):1085-1095.

66 Bullock, D.S. and Nitsi, E.I. 2001. Roundup ready soybean technology and farm production costs: Measuring the incentive to adopt genetically modified seeds. American Behavioral Scientist 44(8):1283-1301.

67 Gardner, J.G. and Nelson, C.H. 2007. Genetically modified crops and labor savings in US crop production. Paper presented at the Southern Agricultural Economics Association Annual Meeting, 4-7 February 2007, University of Illinois at Urbana-Champaign, Mobile, AL.

68 Piggott, N.E. and Marra, M.C. 2008. Biotechnology adoption over time in the presence of non-pecuniary characteristics that directly affect utility: a derived demand approach. AgBioForum 11(1):58-70.

69 Fernandez-Cornejo, J. 2004. The Seed Industry in U.S. Agriculture: An Exploration of Data and Information on Crop Seed Markets, Regulation, Industry Structure, and Research and Development. US Department of Agriculture, Economic Research Service, Agriculture Information Bulletin No. 786. Washington, DC. Available at Web site http:// www.ers.usda.gov (accessed 18 March 2010).

70 USDA-NASS. 2009b. Data and Statistics: Quick Stats. US Department of Agriculture, NASS. Available at Web site http://www.nass.usda.gov (accessed 18 March 2010).

71 Heffernan, W.D. 2000. Concentration of ownership and control in agriculture. In F. Magdoff, J.B. Foster, and F.H. Buttel (eds). Hungry for Profit: The Agribusiness Threat to Farmers, Food, and the Environment. Monthly Review Press, New York. p. 61-76.

72 McMichael, P. 2008. Development and Change: A Global Perspective. 3rd ed. Pine Forge Press, Thousand Oaks, CA.

73 Glenna, L. 2003. Farm crisis or agricultural system crisis: defining national problems in a global economy. International Journal of Sociology of Agriculture and Food 11(1):15-30.

74 Rubinfeld, D.L. 2001. Antitrust policy. In N.J. Smelser and P.B. Baltes (eds). International Encyclopedia of the Social and Behavioral Sciences. Elsevier Science Ltd, Oxford. p. $553-560$.

75 Heffernan, W.H. and Constance, D.H. 1994. Transnational corporations and the globalization of the food system. In A. Bonanno, L. Busch, W.H. Friedland, L. Gouveia, and E. Mingione (eds). From Columbus to ConAgra: The Globalization of Agriculture and Food. University of Kansas Press, Lawrence, KS. p. 29-51.

76 Hendrickson, M. and Heffernan, W. 2007. Consolidation in the Food and Agriculture System. Report to the National 
Farmers Union, Washington DC. Available at Web site: http://nfu.org (accessed 18 March 2010).

77 Boyd, W. 2003. Wonderful potencies? Deep structure and the problem of monopoly in agricultural biotechnology. In R.A. Schurman, D. Doyle, and T. Kelso (eds). Engineering Trouble: Biotechnology and Its Discontents. University of California Press, Berkeley, CA. p. 24-62.

78 Kloppenburg, J.R. Jr. 2004. First the Seed: The Political Economy of Plant Biotechnology: 1942 to 2000. University of Wisconsin Press, Madison, WI.

79 Fernandez-Cornejo, J. 2009. Adoption of Genetically Engineered Crops in the U.S. US Department of Agriculture, Economic Research Service. Washington, DC. Available at Web Site http://www.ers.usda.gov (accessed 18 March 2010).

80 United Nations Conference on Trade and Development. 2006. Tracking the Trend Towards Market Concentration: The Case of the Agricultural Input Industry. United Nations, New York. Available at Web site http://www.unctad.org (accessed 18 March 2010).

81 Davoudi, S. 2006. Monsanto Strengthens its Grip on GM Market: Group Maintains Lead as Billionth Acre goes under Cultivation. Financial Times, 16 November 2006. Available at Web site http://www.ft.com (accessed 18 March 2010).

82 Glenna, L.L. and Cahoy, D.R. 2009. Agribusiness concentration, intellectual property, and the prospects for rural economic benefits from the emerging biofuel economy. Southern Rural Sociology 24(2):111-129.

83 Buttel, F. 2005. Ever since Hightower: the politics of agricultural research activism in the molecular age. Agriculture and Human Values 22(3):275-283.

84 Hassanein, N. 1997. Networking knowledge in the sustainable agriculture movement: Some implications of the gender dimension. Society and Natural Resources 10:251-257.

85 Hassanein, N. 1999. Changing the Way America Farms: Knowledge and Community in the Sustainable Agriculture Movement. University of Nebraska Press, Lincoln, NE.

86 Morgan, K. and Murdoch, J. 2000. Organic vs. conventional agriculture: knowledge, power, and innovation in the food chain. Geoforum 31:159-173.

87 Oerlemans, N. and Assouline, G. 2004. Enhancing farmers' networking strategies for sustainable development. Journal of Cleaner Production 12:469-478.

88 Kroma, M.M. 2006. Organic farmer networks: facilitating learning and innovation for sustainable agriculture. Journal of Sustainable Agriculture 28(4):5-28.

89 Fazio, R.A., Rodriquez Baide, J.M., and Molnar, J.J. 2009. Barriers to the adoption of sustainable agriculture practices: Working farmer and change agent perspectives. Final Report to the Southern SARE, Department of Agricultural Economics and Rural Sociology, Auburn University, Auburn, AL, USA.

90 Lacy, W.B. 2001. Generation and commercialization of knowledge: Trends, implications, and models for public and private agricultural research and education. In S. Wolf and D. Zilberman (eds). Knowledge Generation and Technical Change: Institutional Innovation in Agriculture. Kluwer Academic Publishers, Boston, MA. p. 27-54.

91 Food and Agriculture Organization of the United Nations. 2004. The State of Food and Agriculture. Agricultural Biotechnology: Meeting the Needs of the Poor? Food and Agriculture Organization of the United Nations, Rome, Italy.

92 Ervin, D., Batie, S., Welsh, R., Carpentier, C.L., Fern, J., Richman, N., and Schulz, M. 2001. Transgenic crops: An environmental assessment. Policy Studies Report, Wallace Center for Agricultural and Environmental Policy. Winrock International, Washington, DC.

93 Welsh, R., Hubbell, B., Ervin, D., and Jahn, M. 2002. GM crops and the pesticide paradigm. Nature Biotechnology 20(6):548-549.

94 National Research Council. 2001. Publicly funded agricultural research and the changing structure of U.S. agriculture. Committee to Review the Role of Publicly Funded Agriculture on the Structure of U.S. Agriculture. National Academy Press, Washington, DC.

95 Welsh, R. and Glenna, L. 2006. Considering the role of the university in conducting agri-biotechnology research. Social Studies of Science 36:929-942.

96 Buccola, S., Ervin, D., and Yang, H. 2009. Research choice and finance in university bioscience. Southern Economic Journal 75(4):1238-1255.

97 Murphy, K., Lammer, D., Lyon, S., Carter, B., and Jones, S.S. 2005. Breeding for organic and low-input farming systems: an evolutionary-participatory breeding method for inbred cereal grains. Renewable Agriculture and Food Systems 20(1):45-55.

98 Ceccarelli, S. and Grando, S. 2007. Decentralized-participatory plant breeding: an example of demand driven research. Euphytica 155(3):349-360.

99 Dawson, J.C. 2008. Breeding wheat for efficient $\mathrm{N}$ use in low-input and organic systems in the Pacific Northwest. Unpublished Dissertation, Washington State University, Department of Crop and Soil Sciences. Washington State University, Pullman, WA.

100 Mendum, R. and Glenna, L.L. 2010. Socioeconomic obstacles to establishing a participatory plant breeding program for organic growers in the United States. Sustainability 2:73-91.

101 Dawson, J.C. and Goldberger, J.R. 2008. Assessing farmer interest in participatory plant breeding: who wants to work with scientists? Renewable Agriculture and Food Systems 23(3):177-187.

102 Huffman, W.E., Norton, G., Traxler, G., Frisvold, G., and Foltz, J. 2006. Winners and losers: formula versus competitive funding of agricultural research. Choices 21(4):269274.

103 Graff, G. and Zilberman, D. 2010. Agricultural biotechnology: Equity and prosperity. In J. Popp, M. Jahn, M. Matlock, and N. Kemper (eds). The Role of Biotechnology in a Sustainable Food Supply. Cambridge University Press, New York, forthcoming.

104 Ervin, D. and Welsh, R. 2006. Environmental effects of genetically modified crops: differentiated risk assessment and management. In R.E. Just, J.M. Alston, and D. Zilberman (eds). Regulating Agricultural Biotechnology: Economics and Policy. Springer Publishers, New York. p. 301-326.

105 Batie, S.S. 2008. Wicked problems and applied economics. American Journal of Agricultural Economics 90(5):11761191.

106 Dasgupta, P. and David, P.A. 1994. Toward a new economics of science. Research Policy 23:487-521. 